\title{
Een marketingreflectie op Snacks and the City
}

\author{
Koert van Ittersum
}

(C) The Author(s) 2020

Samenvatting Ik heb met bijzonder veel interesse en waardering het artikel 'Snacks and the City' gelezen, waarin een veldonderzoek wordt beschreven om gezond snacken te promoten. Wat een mooi en waardevol experiment en wat geweldig om hier als hoogleraar Marketing en Consumentenwelzijn vanuit een marketingperspectief op te mogen reflecteren.

Trefwoorden obesogene omgeving · gezonde snacks $\cdot$ marketing $\cdot$ branding

\section{Reflection on Snacks and the City from a marketing perspective}

\begin{abstract}
I have read with great interest and appreciation the article 'Snacks and the City', which describes a field study to promote healthy snacking. What a beautiful and valuable experiment and how wonderful to be able to reflect on this from a marketing perspective as Professor of Marketing and Consumer Welfare.
\end{abstract}

Keywords obesogenic environment · healthy snacks · marketing $\cdot$ branding

Veel mensen denken dat bedrijven met marketing- en brandingactiviteiten consumenten producten kunnen laten kopen waar ze geen behoefte aan hebben. Dat is maar de vraag, want als een product niet in een behoefte voorziet, zullen consumenten het niet aanschaffen. Het feit dat 80 tot $85 \%$ van de fast-moving consumer goods flopt geeft wel aan dat de 'macht'

\author{
K. van Ittersum ( $₫)$ \\ Vakgroep Marketing, Rijksuniversiteit Groningen, \\ Groningen, Nederland \\ K.van.Ittersum@rug.nl
}

van marketing beperkt is. Toch lijkt het soms alsof het aanbod de vraag schept. Dit gebeurt vooral wanneer bedrijven producten introduceren die voorzien in latente behoeften, behoeften waarvan consumenten zichzelf niet bewust zijn. Maar zelfs als een bedrijf hierin slaagt is marktsucces geen garantie. Alles moet kloppen. Deze conclusie lijkt te worden bevestigd door de resultaten van het veldexperiment. Ondanks de grondige en professionele voorbereiding vallen de verkopen van de gezonde snack tegen.

\section{Marketing en branding}

Marketing richt zich in essentie op het optimaal afzetten van goederen en diensten door zo goed mogelijk rekening te houden met de behoeften en specifieke wensen van de (potentiële) kopers. Marketing wordt als zodanig vaak vertaald in de zogenaamde vier P's: activiteiten om het juiste product aan de juiste consument, op de juiste plaats, tegen de juiste prijs aan te bieden en dit met promotie goed te ondersteunen [1].

Naast marketing is er branding. activiteiten die er voor zorg dragen dat de juiste consument op het juiste moment aan het merk denkt (merkbekendheid), zodat positieve en unieke merkassociaties in het hoofd van de consument geactiveerd worden (merkimago), die de kans op aankoop verhogen [2]. Marketing en branding moeten optimaal afgestemd zijn om bij te dragen aan het marktsucces van het product. En dit geldt misschien nog wel meer in de snackcontext van dit onderzoek, waarbinnen consumenten vaak achteloos tot hun keuze komen.

\section{De achteloze consument}

Consumenten nemen ruim 225 voedingsbeslissingen per dag, bijvoorbeeld over of, waar, wat en hoeveel ze gaan snacken wanneer ze met een hongerig ge- 
voel over het stationsplein in Utrecht lopen [3]. Veel van deze beslissingen worden zonder nadenken genomen - de consument opereert op de automatische piloot, waarbij bestaande associaties in het geheugen van grote invloed zijn op de uiteindelijke aankoopbeslissing [4]. Een consument die zich via het stationsplein richting de treinen of juist richting de plaats van bestemming begeeft en zich realiseert behoefte te hebben aan een snack zal op basis van bestaande associaties mogelijk besluiten even snel langs de $\mathrm{AH}$ to go te gaan om daar een Mars te kopen. Wanneer Van Taartjes geen onderdeel is van het juiste associatieve netwerk - het geheugennetwerk waarin de relevante kennisaspecten van een persoon zijn opgeslagen die onderling verbonden worden door associatieve links -, zullen consumenten het product niet in overweging nemen. Sterker nog, de bestaande associaties zullen bijdragen tot selectieve attentie, die de kans op het kopen van Van Taartjes kan verkleinen [4]. Om het marktsucces te verhogen is het van essentieel belang dat Van Taartjes in het juiste associatieve netwerk van consumenten wordt gepositioneerd. Zoals ik hierna aan de hand van de vier P's van marketing zal beschrijven, is dit echter niet zo eenvoudig.

\section{Product}

\section{Productcategorisatie}

Het doel van het veldexperiment was om gezond snacken te stimuleren door het aanbieden van een gezond alternatief. Binnen het experiment is gekozen voor gezonde taartjes. De keuze van dit product en de ontwikkeling ervan zijn overtuigend en op professionele wijze aangepakt. De vraag die echter gesteld kan worden is of consumenten een taartje als een snack percipiëren. Anders gezegd, hoeveel consumenten zullen spontaan 'taartje' antwoorden op de vraag 'Aan wat voor snack zou $\mathrm{u}$ denken wanneer $\mathrm{u}$ over het stationsplein in Utrecht loopt en behoefte hebt aan een snack?' [2]. Ik vermoed dat veel mensen (hartige) taartjes niet direct als snack beschouwen.

Dit lijkt ook bevestigd te worden door de resultaten van het woordassociatieonderzoek dat de onderzoekers hebben uitgevoerd. Wanneer deelnemers aan het onderzoek gevraagd worden naar de meest ideale snacks, dan worden vooral broodjes ('broodje gezond'), fruit en graanrepen genoemd.

Geen van de deelnemers noemt (hartige) taartjes. En producten die niet als snack in het geheugen van consumenten zijn opgeslagen, zullen bij activatie van de snacksproductcategorie niet in overweging worden genomen. Het is niet onwaarschijnlijk dat het taartjesaanbod als gevolg van selectieve attentie genegeerd zal worden [4].

\section{Kwaliteit}

De kwaliteit van het product is een van de belangrijkste factoren die de keuzen van consumenten beïnvloeden. Vaak wordt daarbij aan functionele kwaliteit gedacht - in dit geval: stilt de snack de honger? De kwaliteit van snacks wordt echter ook bepaald door smaak, gezondheid en consumptiegemak. Gegeven de context van dit onderzoek, waarbij consumenten zich te voet verplaatsen, mag je verwachten dat consumptiegemak essentieel is. Dit wordt ook bevestigd in het artikel van De Ridder en collega's (zie elders in dit nummer): consumenten geven aan dat een groentewrap 'lastig te hanteren' is. De vraag die gesteld kan worden is of consumenten denken dat deze taartjes eenvoudig, zonder knoeien en al lopend richting de trein geconsumeerd kunnen worden.

\section{Promotie}

Promotie, of eigenlijk 'communicatie', is essentieel voor het creëren van merkbekendheid en positieve en unieke merkassociaties in de hoofden van consumenten [2]. Om merkbekendheid en associaties te creëren moet een aantal noodzakelijke stappen worden gezet. De consumenten moeten de juiste communicatieboodschap 1) voorgeschoteld krijgen, 2) actief waarnemen, 3) begrijpen en 4) waarderen, en 5) moeten actie ondernemen. Elke stap moet $100 \%$ succesvol worden afgerond [1]. Wanneer elke stap voor $50 \%$ met succes wordt afgerond zal slechts $50 \% \times 50 \% \times 50 \% \times 50 \% \times 50 \%=3,12 \%$ van de benaderde consumenten het product kopen. Dit betekent ook dat wanneer alle snackbehoevende consumenten die over het stationsplein lopen de boodschap over Van Taartjes succesvol krijgen voorgeschoteld $(100 \%)$ en iedereen de boodschap actief tot zich neemt $(100 \%)$ en begrijpt (100\%), dit nog niet hoeft te leiden tot veel verkopen. Stel dat $75 \%$ van de consumenten zich zorgen maakt over het consumptiegemak en nog eens $75 \%$ een voorkeur heeft voor chocolade, dan nog zullen slechts $100 \% \times 100 \% \times 100 \% \times 25 \% \times 25 \%=6,25 \%$ van de snackbehoevende consumenten een Van Taartjes kopen.

De eerlijkheid gebied ook te zeggen dat de kans dat de eerste drie stappen met $100 \%$ succes worden afgerond erg klein lijkt. Het is niet voor niks dat bedrijven veel tijd en geld steken in communicatieactiviteiten, zoals advertenties, reclames en sponsoring, om op die manier hun merken actief in het juiste associatieve netwerk te plaatsen.

\section{Prijs}

Prijs reflecteert de economische waarde van een product. Het is belangrijk dat de prijs past bij de verwachtingen van consumenten. De context waarin het product wordt aangeboden beïnvloedt de perceptie van 
prijzen. Naast de economische waarde kunnen consumenten de prijs van een product ook als kwaliteitssignaal interpreteren, waarbij ze vaak denken dat producten met hogere prijzen van betere kwaliteit zijn. Recent onderzoek laat ook zien dat producten met hogere prijzen als gezonder worden gepercipieerd dan producten met lagere prijzen [5].

Het effect van de prijs op de kwaliteits- en gezondheidsperceptie is belangrijk in de context van het veldexperiment. Ik vraag me af of $€ 2,50$ voor Van Taartjes past bij de verwachtingen van consumenten, die mogelijk denken dat de prijs voor dit specifieke product op deze locatie, aangeboden via een food truck, significant hoger ligt. De prijs van $€ 2,50$ is lager dan de gemiddelde prijs die op het station voor een snack moet worden betaald. Het kan daarom zijn dat consumenten de prijs te laag vinden, wat vervolgens de perceptie van de kwaliteit en de gezondheid negatief beïnvloed kan hebben. Het beperkte effect van de verlaging naar $€ 1,75$ zou erop kunnen wijzen dat $€ 2,50$ reeds een (te?) lage prijs was. Wat dat betreft zou een verhoging van de prijs mogelijk een positief effect op de verkopen kunnen hebben.

\section{Plaats}

Plaats betreft de locatie waar een product wordt verkocht. Het verkoopkanaal heeft een enorme impact op het verwachtingspatroon van consumenten [1]. In het geval van dit veldexperiment kan de food truck beschouwd worden als het verkoopkanaal. Consumenten associëren food trucks met relatief dure producten en denken dat street food vaak een speciaal karakter heeft en ter plekke wordt bereid [1-4, 6]. Vanuit dat perspectief denk ik dat de fruit- en groentetaartjes goed aansluiten bij de consumentenverwachtingen over food trucks. Sterker nog, ik denk dat wanneer deze food truck op een food truck-festival zou staan, er significant meer taartjes verkocht zouden worden. De food truck stond echter op het stationsplein in Utrecht. Ik vermoed dat de beschreven associaties het marktsucces van Van Taartjes in deze specifieke context beperkt zullen hebben [1]. Het prijsimago van food trucks kan de negatieve kwaliteits- en gezondheidsassociaties als gevolg van de relatief lage prijs van de taartjes, zoals hiervoor beschreven, hebben versterkt [2]. Omdat street food meestal eten is dat meteen en zonder bestek geconsumeerd kan worden, kan de food truck mogelijke zorgen over het consumptiegemak van de taartjes hebben versterkt [3]. Het speciale productimago van food trucks heeft de positionering van Van Taartjes als snack mogelijk verder verzwakt [4]. En wanneer food trucks worden geassocieerd met eten dat ter plekke wordt bereid kan dit vraagtekens hebben opgeroepen over de snelheid waarmee een snack gekocht en geconsumeerd kan worden.

\section{Aanbevelingen}

Ik wil allereerst nogmaals mijn waardering uitspreken voor de grondige en professionele voorbereiding van dit veldexperiment. Verder onderken ik uiteraard dat het achteraf makkelijk praten is. Dit gezegd hebbende zou ik de volgende aanbevelingen willen geven.

1. Overweeg om de fruit- en groentetaartjes te vervangen door een product dat meer als daadwerkelijke snack zal worden gepercipieerd. Ik realiseer me dat dit grote implicaties heeft. Mijn verdere aanbevelingen zijn daarom gebaseerd op handhaving van de taartjes.

2. Bij handhaving van de taartjes is het belangrijk de naam van het product aan te passen en sterker als snack te positioneren. Er kan ook nagedacht worden om het product te positioneren als meer dan een snelle snack, namelijk als een substantieel tussendoortje. Van Taartjes lijken meer vergelijkbaar met een belegd broodje, een pizzapunt of een bakje patat, dan bijvoorbeeld een appel of een zakje chips.

3. Bij handhaving van de taartjes is het essentieel dat er hoog ingestoken wordt op het realiseren en communiceren van het consumptiegemak.

4. Gegeven de communicatie-uitdagingen is het waardevol om de taartjes dichter naast alternatieve snacks aan te bieden. Het verkoopkanaal zal daarom aanpassingen behoeven. Op deze manier kunnen de uitdagingen als gevolg van de associaties met food trucks worden beperkt, maar kan Van Taartjes ook profiteren van het associatieve netwerk dat consumenten reeds hebben van bestaande snacks. Het blijft wel zaak dat de aandacht van de consument voor Van Taartjes dan op het verkooppunt verkregen wordt.

5. Ik zou overwegen de prijs te verhogen, en zo de positionering te verscherpen en het product meer in lijn te brengen met vergelijkbaar producten, zoals een belegd broodje, een salade of een pizzapunt.

Open Access This article is licensed under a Creative Commons Attribution 4.0 International License, which permits use, sharing, adaptation, distribution and reproduction in any medium or format, as long as you give appropriate credit to the original author(s) and the source, provide a link to the Creative Commons licence, and indicate if changes were made. The images or other third party material in this article are included in the article's Creative Commons licence, unless indicated otherwise in a credit line to the material. If material is not included in the article's Creative Commons licence and your intended use is not permitted by statutory regulation or exceeds the permitted use, you will need to obtain permission directly from the copyright holder. To view a copy of this licence, visit http://creativecommons.org/licenses/by/4.0/.

\section{Literatuur}

1. BestRJ. Market-based management. 5edruk. Upper Saddle River: Pearson Prentice Hall; 2009. 
2. Keller KL. Strategic brand management. 4e druk. London: Pearson; 2013.

3. Ittersum $\mathrm{K}$ van. The obesity epidemic: it will take the entire village. https://www.ted.com/talks/koert_van ittersum_the_obesity_epidemic_it_will_take_the_entire_ village. Geraadpleegd op 2 maart 2020 .

4. Janiszewski C, Kuo A, Tavassoli NT. The influence of selective attention and inattention to products on subsequent choice. JConsum Res. 2013;39:1258-74.
5. Haws KL, Reczek RW, Sample KL. Healthy diets make empty wallets: the healthy = expensive intuition. J Consum Res. 2017;43:992-1007.

6. Vleuten O van der. Foodtruckfestivals? Daar krijg je diarree (en 7 andere vooroordelen). 2018. https://www.ad.nl/ koken-en-eten/foodtruckfestivals-daar-krijg-je-diarreeen-7-andere-vooroordelen a022f07a. Geraadpleegd op 5 april 2020 